\title{
Conservation Planning in Anthropogenic Landscapes
}

\author{
James Rodríguez-Echeverry ${ }^{1 *}$ and Margareth Leiton ${ }^{2}$ \\ ${ }^{1}$ Director and researcher of the Takiyaco Foundation, Colombia. \\ ${ }^{2}$ Researcher of the Takiyaco Foundation, Colombia
}

Submission: April 25, 2019; Published: May 16, 2019

*Corresponding author: James Rodríguez-Echeverry, Department of Landscape Ecology and Biodiversity Conservation, Takiyaco Foundation, Colombia, America

\begin{abstract}
Landscape-scale conservation planning offers a way out to the ecosystems degradation while ensuring the participation of different levels of governance and the community in this process. The corridor-patch-matrix model is an important strategy for conservation planning in anthropogenic landscapes because it allows the integration of natural and social systems in the conservation process. I recommend the corridorpatch-matrix model, as a landscape-scale conservation approach, because it offers a variety of perspectives on conservation across large areas and transcending multiple boundaries, political and ecological.
\end{abstract}

Keywords: Anthropogenic process; Biodiversity; Corridor-Patch-Matrix Model; Ecosystem services; Landscape changes; Landscape-scale conservation planning; Landscape ecology

\section{Introduction}

\section{Landscape ecology and landscape changes}

Landscape ecology has been widely recognized as a highly interdisciplinary science of heterogeneity [1]. In general, heterogeneity refers to a multiscale structure composed of intertwining patchiness and gradients in space and time. Heterogeneity may be regarded as an essential cause and consequence of diversity and complexity in both natural and social systems, and thus plays a key role in dealing with complexity in theory and practice. Landscape ecology is an interdisciplinary field concerned with how human and natural processes interact to shape function of ecosystems in time and space and how landscapes should be designed to foster sustainability [2]. Landscape ecology has also been considered as "a holistic and transdisciplinary science of landscape study, appraisal, history, planning and management, conservation, and restoration" [3].

In the last decades, many forested landscapes are changing rapidly in response to changes in key social and ecological drivers. Warming climate is altering forest productivity and the distribution of some tree species [4]. Future climate projections suggest that disturbance regimes could change profoundly in coming decades [5]. Change in land use is also ongoing. Forest harvesting continues in many landscapes while slowing in others, and exurban development and thus the extent of wildland-urban interface has increased, especially in forested landscapes with abundant environmental amenities [6]. Collectively, changing drivers will alter landscape heterogeneity and resulting in the reduction of biodiversity and ecosystem services, which are broadly defined as the benefits provided by ecosystems that contribute to making human life both possible and worth living [7].

The greatest impacts on biodiversity have occurred at the native forest habitat level, such as the reduction and habitat loss, generating important changes in the provision of ecosystem services in different regions of the world. The impacts on the diversity of native forest habitat and ecosystem services have occurred due to the increase of the human population [8], which has transformed forest landscapes to anthropogenic landscapes in the last decades [9]. The need to conserve habitat diversity and ecosystem services within forest and anthropogenic landscapes has been recognized by practitioners [10]. The conservation of both resources would help to ensure the maintenance of multiple benefits for human populations that inhabit them.

\section{Landscape-scale conservation planning}

Landscape-scale conservation planning is closely related to the field of landscape ecology. Over the last decade, I have seen an increased emphasis on landscape perspectives in environmental planning at multiple scales because maintaining and restoring key landscape elements at multiple spatial scales may be critical in sustaining a wide range of ecosystem functions and services. Consequently, landscape-scale conservation planning offers 
a way out to the ecosystems degradation while ensuring the participation of different levels of governance and the community in this process. In this sense, it is important to highlight the corridor-patch-matrix model, as an important strategy for conservation planning in anthropogenic landscapes. This model is appropriate when the configuration of the landscape consist the native forest restricted to small patches sparsely distributed across the landscape. The main objective of the corridor-patchmatrix model is to maintain the quality and quantity of patches of native forest through management of the matrix. The condition of the matrix may be more important in determining the survival of the species and provision of ecosystem services than the isolation of patches $[11,12]$. Therefore, the management of the matrix should focus on sensitive buffer areas that improve the connectivity between forest patches and increase the ability of the matrix to support the biodiversity and ecosystem services. The planning and implementation of the corridor-patch-matrix model implies the commitment and active participation of governments and the community in general on a local and global scale.

\section{Conclusion}

I recommend a landscape-scale conservation approach because it offers a variety of perspectives on conservation across large areas and transcending multiple boundaries, political and ecological. I consider that the landscape-scale is a highly relevant development for conservation and happens when a landscape-scale conservation planning initiative may act as an umbrella for landowners, managers, and local planners from multiple jurisdictions to collaborate on making decisions to achieve regional conservation goals. Moreover, I consider that the corridor-patch-matrix model, as an important strategy for conservation planning in anthropogenic landscapes because it allows the integration of natural and social systems in the conservation process.

\section{References}

1. Wu J (2006) Landscape ecology, cross-disciplinarity, and sustainability science. Landscape Ecol 21(1): 1-4.

2. Wu J (2013) Landscape sustainability science: ecosystem services and human well-being in changing landscapes. Landscape Ecol 28(6): 9991023.

3. Naveh Z, Lieberman AS (1994) Landscape Ecology: Theory and Application. Springer-Verlag, New York.

4. Lenoir J, Gegout JC, Dupouey JL, Bert D, Svenning JC (2010) Forest plant community changes during 1989-2007 in response to climate warming in the Jura Mountains. J Veg Sci 21(5): 949-964.

5. Westerling AL, Turner MG, Smithwick EAH, Romme WH, Ryan MG (2011) Continued warming could transform Greater Yellowstone fire regimes by mid-21st century. Proc Nat Acad Sci USA 108: 1316513170.

6. Carpenter SR, Pingali P, Bennet EM, Zurek MB (2005) Millennium Ecosystem Assessment Ecosystems and human well-being: Scenarios. Millennium Ecosystem Assessment. Island Press, Washington DC.

7. Pan Y, Xu Z, Wu J (2013) Spatial differences of the supply of multiple ecosystem services and the environmental and land use factors affecting them. Ecosyst Serv 5: 4-10.

8. Rodríguez-Echeverry J, Echeverría C, Oyarzún C, Morales L (2018) Impact of land-use change on biodiversity and ecosystem services in the Chilean temperate forests. Landscape Ecol 3(3): 439-453.

9. Iverson L, Echeverria C, Nahuelhual L, Luque S (2014) Ecosystem services in changing landscapes: an introduction. Landscape Ecol 29(2): 181-186.

10. Rodríguez Echeverry J, Echeverría C, Nahuelhual L (2015) Impacts of anthropogenic land-use change on populations of the Endangered Patagonian cypress Fitzroya cupressoides in southern Chile: implications for its conservation. Oryx Int J Conserv 49(3): 447-452.

11. Rodríguez-Echeverry J, Echeverría C, Oyarzún C, Morales L (2017) Spatial Congruence between Biodiversity and Ecosystem Services in an Anthropic Landscape in Southern Chile: Basis for Conservation Planning. Bosque 38 (3): 495-506.

\begin{tabular}{l} 
Your next submission with Juniper Publishers \\
will reach you the below assets \\
- Quality Editorial service \\
- Swift Peer Review \\
- Reprints availability \\
- E-prints Service \\
- Manuscript Podcast for convenient understanding \\
- Global attainment for your research \\
- Manuscript accessibility in different formats \\
( Pdf, E-pub, Full Text, Audio) \\
- Unceasing customer service \\
Track the below URL for one-step submission \\
https://juniperpublishers.com/online-submission.php \\
\hline
\end{tabular}

